\title{
Palm oil sustainability partnership: implementation and connection with farmers income
}

\author{
Ernawati Hamid ${ }^{1}$, Zakky Fathoni², and Mirawati Yanita ${ }^{3}$ \\ ${ }^{1}$ Agribusiness Department, Faculty of Agriculture, University of Jambi, Jalan Raya Jambi-Muara \\ Bulian Km 15, Jambi Indonesia \\ ${ }^{2}$ Agribusiness Department, Faculty of Agriculture, University of Jambi, Jalan Raya Jambi-Muara \\ Bulian Km 15, Jambi Indonesia \\ ${ }^{3}$ Agribusiness Department, Faculty of Agriculture, University of Jambi, Jalan Raya Jambi-Muara \\ Bulian Km 15, Jambi Indonesia
}

\begin{abstract}
Partnership is a business strategy that performed by two or more parties in a certain period to obtain the benefits together with the principle of mutual need and mutual rearing. The study aims to observe and assess the implementation of the oil palm agribusiness partnerships and analyze the level of farmers' income. This research used a survey method. Descriptive analysis is used in data analysis, to provide an overview of the implementation of partnerships applied by oil palm plantation companies in Jambi Province. The results showed that agribusiness partnerships that implemented by the palm oil company basically has managed to create independent farmers who can canalize the aspirations of farmers, both in KKPA and PIR Trans pattern. Empirically, the maximum value and benefit aspects of process management partnerships as an indicator of the level of performance partnerships oil palm plantation companies in Jambi Province is quite high, has reached $82.5 \%$. But these facts have not been fully supported by a partnership of cooperation actors, in the sense that the level of achievement of the implementation aspects of the value of partnership firm activities and performance of oil palm plantations has reached approximately $71 \%$
\end{abstract}

\section{Introduction}

Agribusiness partnership is a form of cooperation between small and medium-sized businesses or large businesses along with business coaching and development by medium/large businesses with the principle of mutual need, mutually reinforcing and mutually beneficial. Agribusiness partnership aims to 1) increase the income of small businesses and communities, 2) increase the benefit for the acquisition of partnership actors, 3) improve equity and the empowerment of communities and small businesses, 4) 
improve rural economic growth and national territory, 5) expand job opportunities and 6) increase the resilience of the national economy [7].

Partnership of oil palm plantation companies and industries in Jambi Province has started with a design such as PIR, creditor and is now famous for its independent partnerships (partnerships that historically generation II / PRP), which form partnerships that have developed between the company (core) with farmers via cooperatives (plasma). When cooperative or farmer stronger, the corporate exploitation to the farmers are not much and vice versa if the farmer or cooperative are weak, the partnership will give more benefits to oil palm company that will be reflected from the letter of partnership agreement [4].

Asymmetrical and exploitative practices in plantation business partnership relationships, such as decision-making in business activity is determined more by the core companies or other parties (such as governments) that have greater strength, also not optimal on distribution of value-added benefits that should be enjoyed by the farmers make the imbalance of the system led to a partnership. Farmers only act as a complement to the partnership structure [14] .

Farmer participation, both individually and collectively are still very rare (especially in post-harvest activities) due to limitations in the ability of farmers to follow a high-tech process. Meanwhile, the development of the plantation business partnership is needed, because: 1) the demands of society (local) including redistributing business opportunities, asset production, business benefits to farmers, 2) the global challenges of conducting plantation business, which is "seized" that controls the downstream industry and seize the largest margin industrial production inputs burden of production costs of farmers and planters $[5,10,14]$.

The challenges which are faced in the development of plantation system in the framework of the development of agribusiness among others are the limited supply of data and information technology, resources and markets, lack of support and initiatives from various related functions at all levels in the growing interest and participation of the community and the business world. Other challenges in agribusiness development are lack of support infrastructure such as roads, ports, means of communication and transportation in the area of development; tariff and non-tariff barriers, including the application of international trade standards are more rigorous; institutional planters who have established businesses, as well as the emergence of a new competitor countries [5, 10, 14].

In the processing and quality product aspects, the challenges are the absence of an integrated policy between upstream and downstream globally, unavailability of commodities development road map that agreed by all parties and being the reference for them. Product which has good quality still not received proportional incentives/ reasonable, strict demand of consumer for quality requirements, and the low interest of investors to develop the downstream industry since the absence of guarantee for certainty of sustainable business $[6,8,9,13,15]$.

In the institutional aspect, the challenges are the community cultures that still individuals in managing their plantation, the demand to increase government revenue as VAT for primary products estates, levies, and charges. Other challenges in institutional aspects are absence of institutional commodity with authority / full authority in the development of commodity; and absence of commodity fund raising policies for commodities $[4,11,12]$.

\section{Method}

The design used in this study is descriptive verification, the research aims to gain an overview of the characteristics of the study variables and conduct a careful examination of 
all variables/indicators of oil palm agribusiness partnerships. The data of this research consists of primary and secondary data. The source of primary data is taken from the farmers participating in the partnership, and the age of their oil palm trees is more than 5 years. Interviews, observations, and study literatures are used in this research in order to gather the data. Descriptive analysis is used to provide an overview of the implementation of the partnership implemented by oil palm plantation companies in Jambi Province [4].

Descriptive analysis method is used to give an overview of the implementation of partnership pattern implemented by oil palm company in Jambi Province. To find out the implementation of the partnership pattern can be seen from the conversion of plasma plantation, the determination of MOU, the division of plasma plantation, the installment/credit of plasma plantation, the institution, the pricing of FFB and the production of FFB. Descriptive data analysis is an ongoing, repetitive and continuous effort. Data analysis in this study took place along with the data collection process, which includes three lines, namely data reduction, data presentation and conclusion (Miles and Huberman, 1994). To calculate the income level of farmers, which is the third objective of this study, the different pattern of partnerships in the oil palm plantation company of Jambi Province can be mathematically used as follows: a. Revenue, operationally it is calculated by: $\mathrm{TR}=\mathrm{PX} \times \mathrm{Q}$ where: $\mathrm{PX}=$ The price of fresh oil palm bunches received by plasma farmers at the revised corporate level $(\mathrm{Rp} / \mathrm{Kg}) . \mathrm{Q}=$ Average production that farmers have sold to KUD based on January - December 2010 period. TR = Total revenue received by smallholders in the period January - December 2010. b. Income, operationally it is calculated by: $\mathrm{I}=\mathrm{TR}-\mathrm{TC}$, where: $\mathrm{TR}=$ Total revenue received by smallholders in the period January - December 2010. TC = Total cost incurred to pay the costs to be paid by farmers to plasma cooperatives every month during the period of January - December 2010. $\mathrm{I}=$ Gross revenue earned by oil palm farmers from January - December 2010. Data analysis was done by describing the gross income obtained by farmers participating in PIR Trans partnership pattern in oil palm plantation company of PT. Agrowiyana and PT. Kirana Sekernan for a period of one year [4].

\section{Results and discussion}

A successful of partnership business strategy is largely determined by the compliance between the partners in running the business ethics. Detailed implementation partnership PIR-Trans (PT Agrowiyana) and creditor (PT Kirana Sekernan) with plasma farmers can be explained as follows: $[4,8,9,15]$

Table 1. Aspects and indicators of implementation on KKPA and PIR trans patterns.

\begin{tabular}{|c|l|l|l|}
\hline No. & $\begin{array}{c}\text { Variable } \\
\text { Implementation } \\
\text { Partnership }\end{array}$ & \multicolumn{2}{|c|}{ Partnership } \\
\cline { 3 - 4 } & $\begin{array}{l}\text { Conversion } \\
\text { smallholding }\end{array}$ & $\begin{array}{l}\text { Pefore the conversion was not charged } \\
\text { loan payments. After the conversion } \\
\text { gets 30\% cost burden for installment } \\
\text { credit. }\end{array}$ & $\begin{array}{l}\text { Before the conversion is charged } \\
\text { to credit payments begin on the } \\
\text { first harvest. After the conversion } \\
\text { gets 30\% cost burden for } \\
\text { installment credit. }\end{array}$ \\
\hline 2. & Determination MOU & $\begin{array}{l}\text { Bank credit can be transferred from } \\
\text { the account of the cooperative / } \\
\text { plasma to account for distribution to } \\
\text { the plasma core in the form of } \\
\text { agricultural inputs are channeled } \\
\text { through the company. }\end{array}$ & $\begin{array}{l}\text { Bank credit can be transferred } \\
\text { from the account of the } \\
\text { cooperative / plasma to account } \\
\text { for distribution to the plasma core } \\
\text { in the form of agricultural inputs } \\
\text { are channeled through the } \\
\text { company. }\end{array}$ \\
\hline
\end{tabular}




\begin{tabular}{|c|l|l|l|}
\hline 3. & $\begin{array}{l}\text { Distribution } \\
\text { smallholding }\end{array}$ & $\begin{array}{l}\text { Determining plots by means drawn } \\
\text { from a stretch of up to individuals. }\end{array}$ & $\begin{array}{l}\text { Distribution plots established by } \\
\text { cooperatives in collaboration with } \\
\text { the company. }\end{array}$ \\
\hline 4. & $\begin{array}{l}\text { Installment/credit } \\
\text { smallholding }\end{array}$ & $\begin{array}{l}\text { Installment loans with 30\% of the } \\
\text { cutting garden products smallholders } \\
\text { and farmers receive 70\% of the } \\
\text { gardens, lasted until the end of the } \\
\text { loan installments. }\end{array}$ & $\begin{array}{l}\text { Installment loans with 70\% of the } \\
\text { cutting garden products } \\
\text { smallholders and farmers receive } \\
30 \% \text { of the garden, done before } \\
\text { the conversion. After conversion, } \\
\text { the farmer receives 70\% and 30\% } \\
\text { of the product is cut garden } \\
\text { installment payment credit. }\end{array}$ \\
\hline 5. & Institutional & $\begin{array}{l}\text { PIR Trans has a cooperative 5 to 5 sub } \\
\text { units, in cooperation with companies } \\
\text { in the areas of: sales TBS, payment for } \\
\text { farmers, interest-free loans, and credit } \\
\text { deposit. }\end{array}$ & $\begin{array}{l}\text { Patterns KKPA cooperate with } \\
\text { one cooperative in the areas of: } \\
\text { sales TBS, payment for farmers, } \\
\text { lending money without interest, } \\
\text { channeling subsidized and non- } \\
\text { subsidized fertilizer, and credit } \\
\text { deposit. Provide basic food and } \\
\text { some snacks. }\end{array}$ \\
\hline 6. & FFB pricing & $\begin{array}{l}\text { 67\% PIR Trans farmers are satisfied } \\
\text { with the price set by Disbun (Regional } \\
\text { Estate Service), 33\% other farmers } \\
\text { want the price as high FFB time } \\
\text { before the global crisis hit. }\end{array}$ & $\begin{array}{l}\text { All farmers KKPA pattern was } \\
\text { quite satisfied with the price set by } \\
\text { Disbun (Regional Estate Service) }\end{array}$ \\
\hline 7. & $\begin{array}{l}\text { Production smallholding very varied, } \\
\text { due to maintenance activities of each } \\
\text { farmer is different. }\end{array}$ & $\begin{array}{l}\text { Production has roughly the same, } \\
\text { due to the maintenance of the } \\
\text { garden to harvest simultaneously } \\
\text { in a single stretch. }\end{array}$ \\
\hline Production & $\begin{array}{l}\text { Payments or the sale of TBS depend } \\
\text { on each KUD, there are 2 weeks and } \\
\text { there is 1 month. }\end{array}$ & $\begin{array}{l}\text { Payments or the sale of FFB } \\
\text { performed 1 month and salary } \\
\text { taken by the head of each farmer } \\
\text { groups with payment details and } \\
\text { pieces if it has debt, credit, or } \\
\text { other purchases through the } \\
\text { cooperative. }\end{array}$ \\
\hline
\end{tabular}

The income of the farmers is the revenue from the oil palm production that is sold to palm oil factory. It will be processed and produces Crude Palm Oil (CPO) and palm kernel. One of the most decisive factors on farmers income is the production of oil palm.

Differences in income received by farmers PIR-Trans and KKPA patterns due to the difference in average production, where the average farmer production PIR-Trans is greater than the average production of KKPA. The difference is due to the production of the differences between the applications of patterns during maintenance until harvest. In this case a partnership with farmers PIR-Trans plantation company more profitable for farmers in terms of production [4].

Table 2. Farmers average revenue per month PIR-Trans and KKPA.

\begin{tabular}{lrrr}
\hline \multicolumn{1}{c}{ Variables } & PIR-Trans & \multicolumn{1}{c}{ KKPA } & Difference \\
\hline Receipts (IDR) & $5,529,893$ & $5,392,992$ & 136,901 \\
Cost (Rp) & 443,597 & 414,280 & 29,317 \\
Revenue (IDR) & $5,086,296$ & $4,978,712$ & 107,584 \\
\hline
\end{tabular}


In its application, the company has always been help farmers to increase production. The company always supervise and provide necessary assistance to farmers to increase production or also to assist farmers in overcoming problems that can interfere with the production of Oil Palm. In addition KUD also plays an active role as an intermediary between the company and farmers. KUD also can help farmers so that farmers can apply for a loan to be able to expand its land bank so that production also increased $[4,8,9]$.

In KKPA patterns, the company conducts surveillance on farmers while harvesting, while in a maintenance company did not provide special assistance for farmers to increase production of oil palm. KUD also plays an active role as an intermediary between farmers and companies, it is just the location of the garden with KUD far enough to make farmers cooperatives when it comes to sharing only. Conditions of KKPA farmer who worked in his garden together in one plot also affects farmers' production. In this case,farmers' creditor patterns always share equally the amount of production obtained in each expanse. So, the amount of production that farmers obtained is relatively similar $[4,8,9]$.

\section{Conclusion}

Agribusiness partnerships implemented by the palm oil company has managed to create independent farmers who can channel the aspirations of farmers, both the pattern KKPA and PIR Trans. Farmers 'income who has become participants in partnership oil palm plantation companies in Jambi Province is quite high, as demonstrated by the average income of farmers PIR Trans and farmers' income patterns each creditor per month or \$ 410.91 USD 5,086,296 and USD 4,978,712 or \$ 402.22 (calculated based on the value of \$ $1=$ USD \$ 12.378 in December 2014).

\section{Reference}

1. Badan Penelitian dan Pengembangan Pertanian. Prospek dan Arah Pengembangan Agribisnis Kelapa Sawit. Edisi Kedua. Departemen Pertanian. (2007)

2. Direktorat Jenderal Perkebunan. Pedoman Umum Program Revitalisasi Perkebunan (Kelapa Sawit, Karet dan Kakao). Departemen Pertanian. (2007)

3. E. Hamid. Peranan PIR Khusus II Perkebunan Kelapa Sawit Sungai Bahar dalam Pengembangan Wilayah Kabupaten Daerah Tingkat II Batang Hari. Tesis Program Pascasarjana Universitas Padjadjaran Bandung. (1994)

4. E. Hamid. Implementasi Kemitraan Agribisnis Kelapa Sawit dan Analisis Pendapatan Petani Peserta Di Provinsi Jambi. Penelitian Disertasi Doktor, Universitas Padjadjaran Bandung. (2012)

5. H. Haeruman. Kemitraan dalam Pengembangan Ekonomi lokal: Bunga Rampai. Jakarta: Yayasan Mitra Pembangunan Desa-Kota. (2001)

6. I. Pahan. Panduan Lengkap Kelapa Sawit Manajemen Agribisnis dari Hulu hingga Hilir. Penebar Swadaya, Jakarta. (2010)

7. M. J. Hafsah. Kemitraan Usaha: Konsepsi dan Strategi. Pustaka Sinar Harapan, Jakarta. (2000)

8. Peraturan Menteri Pertanian Nomor : 33/Permentan/OT.140/7/2006 tentang Pengembangan Perkebunan Melalui Program Revitalisasi Perkebunan. Ditetapkan di Jakarta pada tanggal 26 Juli 2006.

9. Peraturan Pemerintah Republik Indonesia Nomor 44 Tahun 1997 tentang Kemitraan. Ditetapkan di Jakarta pada tanggal 17 November 1997. 
10. Rante Tondok, A. Peranan Perkebunan Besar Sebagai Mitra Perkebunan Rakyat. Majalah media Perkebunan, Nomor 15 April 1997. (1997)

11. Sihombing, R.S.M. Kemitraan usaha dalam Pemberdayaan UKM (Usaha Kecil Menengah) (Studi tentang pelaksanaan kemitraan usaha dalam upaya memberdayakan UKM tenun ulos di Kabupaten Toba Samosir, Sumatera Utara). Tesis Pascasarjana Administrasi Negara Fakultas Ilmu Sosial dan Politik Universitas Gadjah Mada Yogyakarta. (2004)

12. S. Mangoensoekarjo dan H. Semangun. Manajemen Agrobisnis Kelapa Sawit (Gadjah Mada University Press, 2005)

13. Sunarko. Budidaya dan Pengelolaan Kebun Kelapa Sawit dengan Sistem Kemitraan. Penerbit PT. AgroMedia Pustaka, Jakarta. (2009)

14. U. Fadjar. Kemitraan Usaha Perkebunan: Perubahan Struktur yang Belum Lengkap. Forum Penelitian Agro Ekonomi 24, 1, (2006)

15. Undang-Undang Republik Indonesia Nomor 18 Tahun 2004 tentang Perkebunan. Ditetapkan di Jakarta pada tanggal 11 Agustus 2004. 